\title{
Impact of Irrigation Water Salinity on Germination and Seedling Growth of Egyptian Barley Cultivars
}

\author{
Farid Hellal ${ }^{1}$, Ahmad Amer ${ }^{2}$, Kadria EL Azab ${ }^{2}$ and Raafat Zewainy ${ }^{1}$ \\ 1. Plant Nutrition Dept., National Research Centre, Dokki, El-Behouth St., Cairo 12622, Egypt \\ 2. Soils, Water and Environ. Res. Institute, Agric. Res. Center (ARC), Giza 12619, Egypt
}

\begin{abstract}
The aim of this research was to assess the influence of saline irrigation water which prepared to obtain salt stress of 0.31 , $3.21,5.74,8.28$ and $12.86 \mathrm{dS} / \mathrm{m}$ on seed germination, and early seedling growth of 10 cultivars (Giza 123, 124, 125, 126, 127, 129, 130, 134, 135 and 2000) of Egyptian barley grown in clay loam soil. Germination was tested in germination cups filled with clay loam soil moistened with different concentrations of saline water, in the growth chambers condition. Results indicated that, the highest values of germinated seeds were recorded mainly at fresh water $(0.31 \mathrm{dS} / \mathrm{m})$ at all germination periods. Also, the maximum values were recorded at investigated barley cultivars Giza 126, 127 and 2000 for three studied periods (3, 5 and 7 d), while Giza 129, 130 and 135 got the same trend where the highest values for germinated seeds attained at the $5 \mathrm{~d}, 7 \mathrm{~d}$ and at $3 \mathrm{~d}$ were 9.5 seeds, respectively. Barley cultivar Giza 126 had significantly higher root length $(4.07 \mathrm{~cm})$, shoot length $(11.75 \mathrm{~cm})$, root fresh weight $(48.2$ $\mathrm{mg}$ ), shoot fresh weight $(101.1 \mathrm{mg})$, root dry weight $(7.1 \mathrm{mg})$, shoot dry weight $(6.6 \mathrm{mg})$ and seedling vigor index (13.44). The $6 \mathrm{kDa}$ protein bands had the same increasing after salt stress in cultivars Giza 123, 127, 129, 134 and 135. Barley cultivars in clay soil can be classified into barley cultivars Giza 126, 127 and 2000 as highly tolerance and barley cultivar Giza 129, 123 and 127 as moderately tolerance and the rest is less.
\end{abstract}

Key words: Germination, plant length, barley cultivars, salt stress, clay loam soil.

\section{Introduction}

Crop production in arid and semi-arid regions is restricted by soil salinity and soil moisture deficiencies. Salinity in soil or irrigation water is the major limiting factor for crop growth in many regions of the world $[1,2]$. Salt stress at any stage of crop growth can cause an irreversible loss in yield potential in many crops including barley [3, 4]. However, seed germination and seedling establishment are the periods when barley is most sensitive to salinity [5].

Germination and seedling growth are reduced in saline soils with varying responses for species and cultivars. Salinity may also affect the germination of seeds by creating an external osmotic potential that prevents water uptake or due to the toxic effects of

Corresponding author: Farid Hellal, professor, research fields: plant nutrition and soil fertility.
$\mathrm{Na}^{+}$and $\mathrm{Cl}^{-}$on the germinating seed [6]. Seed germination is one of the most fundamental and vital phases in the growth cycle of plants that determine plant establishment and the yield of the crops.

Salinity has many-fold effects on the germination process: it alters the imbibitions of water by seeds due to lower osmotic potential of germination media [7], causes toxicity which changes the activity of enzymes of nucleic acid metabolism [8], alters protein metabolism [9] and reduces the utilization of seed reserves [10]. It may also negatively affect the ultra structure of cell, tissue and organs [11]. However, there are various internal (plant) and external (environmental) factors that affect seed germination under saline conditions which includes nature of seed coat, seed dormancy, seed age, seed polymorphism, seedling vigor, temperature, light, water and gasses [12].

Rapid and uniform field emergence is vital for 
achieving maximum yield and quality of annual crops [13] such as barley. Under salinity conditions, exogenous application of plant growth regulators (PGRs) may overcome much of the internal PGR deficiency and mitigate salinity-induced inhibitory effects [14]. The present study was, therefore, undertaken in order to compare the effects of iso-osmotic stresses induced by irrigation water salinity on germination components of Egyptian barley cultivars grown in clay loam soil.

\section{Materials and Methods}

This study was carried out as a factorial experiment based on completely randomized design (CRD) with three replicates at the growth chamber of Plant Biotechnology Department, National Research Centre, Egypt.

Treatments comprised five salt stress levels and 10 barley cultivars brought from Barley Department, ARC, Egypt. The barley cultivars (Giza 123, 124, 125, $126,127,129,130,134,135$ and 2000) were subjected to saline water varying in salinity levels. Saline water treatments were: tap fresh water $(0.31$ $\mathrm{dS} / \mathrm{m}$, as control), 3.21, 5.74, 8.28 and $12.86 \mathrm{dS} / \mathrm{m}$. Ten barley seeds were sown in germination cups (5 $\mathrm{cm}$ length $\times 10 \mathrm{~cm}$ diameter) filled with $200 \mathrm{~g}$ clay loam soil moistened with different concentration of saline water, in the growth chambers. Growth chamber conditions were $23{ }^{\circ} \mathrm{C}$ day $/ 18{ }^{\circ} \mathrm{C}$ night, $16 \mathrm{~h} / 8 \mathrm{~h}$ light/dark photoperiod, $60 \%$ humidity, photon flux density and $400 \mu \mathrm{mol} / \mathrm{m}^{2}$ s photo synthetically active radiations. Soil moisture content was kept at needs amount of field capacity during the period of the experiment. Germinated seeds were counted every $2 \mathrm{~d}$ for $8 \mathrm{~d}$. Seeds were considered germinated when 2 $\mathrm{mm}$ of the parties was visible. At this stage, germination component was calculated according to Ref. [15].

Germination percentages (G\%) were calculated as total number of germinated seeds by total number of seed used into 100. Germination rate (GR) was calculated as the summation of newly germinated seeds on each day divided by number of days that elapsed since onset of imbibitions with seed numbers adjusted to a base of 100 . The seedling vigor index (SVI) was calculated as shoot and root length into germination percentage divided by 100 .

Root length, shoot length, root fresh weight, shoot fresh weight, root dry weight and shoot dry weight were evaluate. Root: shoot ratio was calculated as root length divided by shoot length into 100 . Root and shoot dry weight was obtained after drying at $70{ }^{\circ} \mathrm{C}$ for $48 \mathrm{~h}$. Tissue water content (TWC) was calculated as shoot fresh weight minus shoot dry weight divided by shoot fresh weight into 100 .

\subsection{Protein Extraction}

The extraction for total soluble protein was done as suggested by Larkindale and Huang [16]. A $0.5 \mathrm{~g}$ of leaves was harvested and ground to a fine powder in liquid nitrogen. Ground powder was homogenized in $1.5 \mathrm{~mL}$ of cold phosphate buffer $(100 \mathrm{mM}, \mathrm{pH} 7.0)$ containing $1 \%$ polyvinylpyrrolidone (PVP) and $1 \mathrm{mM}$ EDTA and then centrifuged at $4{ }^{\circ} \mathrm{C}$ for $15 \mathrm{~min}$ at $10,000 \times$ g. Protein present in the supernatant was measured by a modification of the Bradford method [17] using crystalline bovine albumin to establish a standard curve. The supernatant was separated and stored at $-20{ }^{\circ} \mathrm{C}$ till use.

\subsection{Poly Acrylamide Gel Electrophoresis of Proteins}

SDS-PAGE was performed as described by Laemmli [18]. Protein samples were prepared by mixing with equal volume of $2 \times$ sample buffer $(100$ $\mathrm{mM}$ Tris-HCl, $\mathrm{pH} 6.8,4 \%$ SDS, $20 \%$ glycerol, $4 \%$ $\beta$-mercapto ethanol, $0.01 \%$ bromo phenol blue). Samples boiled for $5 \mathrm{~min}$ prior to loading. Electrophoresis was carried out first at $50 \mathrm{~V}$ for proper stacking and then at constant voltage of $100 \mathrm{~V}$ to resolve the gel. Electrophoresis was carried out using vertical gel electrophoresis apparatus (Bio-Rad) with glass plates $9 \mathrm{~cm} \times 10 \mathrm{~cm}$ with $1.5 \mathrm{~mm}$ spacer. Glass 
plates, spacers, combs and buffer reservoirs of the gel apparatus were thoroughly cleaned with detergent, rinsed and dried. A monomer solution for the appropriate resolving gel was prepared by combining all reagents, except ammonium per sulfate and TEMED. Then APS and TEMED were gently mixed into monomer solution and the mixture was poured between the gel plates with the help of a pipette up to the mark delimiting the resolving gel. It was immediately over layered with distilled water. Polymerization was achieved in approximately $30 \mathrm{~min}$ at room temperature. Gels were either electro blotted onto the nitrocellulose membrane (Hybond-C, Amersham, England) or stained with $0.25 \%$ Coomassie Blue R-250.

The data were statistically analyzed according to Ref. [19]. The least significant differences (LSD) were used to compare differences among treatment means at $5 \%$ level.

\section{Results and Discussion}

The initial soil physical and chemical properties and irrigation water treatments and its properties were shown in Tables 1 and 2 . The irrigation water salinity used in the range from fresh water $(0.31 \mathrm{dS} / \mathrm{m})$ up to very high salinity $(12.86 \mathrm{dS} / \mathrm{m})$. The soil used in the experiment was clay loam in texture, alkaline in reaction, saline $(4.5 \mathrm{dS} / \mathrm{m})$ in soil paste and high in calcium carbonate content.

\subsection{Number of Germinated Seeds}

Table 3 and Figs. 1 and 2 presented the effect of the investigated barley cultivars and water salinity $(0.31$, $3.21,5.74,8.28$ and $12.86 \mathrm{dS} / \mathrm{m}$ ) on the germinated seeds at different periods ( 3,5 and $7 \mathrm{~d}$ ) length of the root and shoot at the end of the germination test and root/shoot percentage as well as final germination rate and percentage.

Regarding to the germinated seeds at different periods ( 3,5 and $7 \mathrm{~d})$, data indicated that the highest values were recorded mainly at fresh water $(0.31 \mathrm{dS} / \mathrm{m})$ at all periods under examined barley cultivars. Also, the maximum values were recorded at barley cultivars Giza 126, 127 and 2000 for three studied periods, while Giza 129, 130 and 135 got the same trend where the highest values for germinated seeds attained at the $5 \mathrm{~d}, 7 \mathrm{~d}$ and at $3 \mathrm{~d}$ were 9.5 seeds, respectively. According to the effect of investigated barley cultivars on the germinated seeds at different periods, data in Table 3 illustrated that after $3 \mathrm{~d}$, Giza 126 got the highest value while after 5 d Giza 127 (9.2), Giza 135 (9.1) and Giza $126(9.0)$ recorded the maximum

Table 1 Irrigation water properties used in the experiment.

\begin{tabular}{|c|c|c|c|c|c|c|c|c|c|c|}
\hline \multirow{2}{*}{$\begin{array}{l}\text { Electrical } \\
\text { conductivity } \\
(\mathrm{dS} / \mathrm{m})\end{array}$} & \multirow{2}{*}{$\begin{array}{l}\text { Sodium } \\
\text { adsoption } \\
\text { ratio }(\%)\end{array}$} & \multirow{2}{*}{$\begin{array}{l}\text { Osmotic } \\
\text { pressure } \\
\text { (bar) }\end{array}$} & \multicolumn{4}{|c|}{ Cations (me/L) } & \multicolumn{4}{|c|}{ Anions (me/L) } \\
\hline & & & $\mathrm{Na}$ & $\mathrm{K}$ & $\mathrm{Ca}$ & $\mathrm{Mg}$ & $\mathrm{CO}_{3}$ & $\mathrm{HCO}_{3}$ & $\mathrm{Cl}$ & $\mathrm{SO}_{4}$ \\
\hline 0.31 & 2.46 & -0.11 & 2.44 & 0.19 & 1.61 & 0.35 & 0.00 & 2.07 & 3.42 & 0.71 \\
\hline 3.21 & 14.40 & -1.16 & 25.33 & 0.23 & 4.27 & 1.92 & 0.00 & 3.38 & 29.30 & 1.30 \\
\hline 5.74 & 17.61 & -2.07 & 44.21 & 0.34 & 8.58 & 4.02 & 0.00 & 4.73 & 53.70 & 2.20 \\
\hline 8.28 & 21.09 & -2.98 & 67.05 & 0.43 & 15.10 & 5.12 & 0.00 & 6.08 & 83.10 & 3.91 \\
\hline 12.86 & 26.73 & -4.63 & 98.74 & 0.54 & 19.87 & 7.43 & 0.00 & 16.76 & 95.66 & 7.23 \\
\hline
\end{tabular}

Table 2 The physicochemical properties of experimental soil.

\begin{tabular}{|c|c|c|c|c|c|c|c|}
\hline Textural class & $\%$ Sand & $\%$ Silt & $\%$ Clay & $\mathrm{pH}$ & $\mathrm{EC}(\mathrm{dS} / \mathrm{m})(1: 5)$ & $\mathrm{CaCO}_{3} \%$ & $\begin{array}{l}\text { Organic } \\
\text { matter \% }\end{array}$ \\
\hline Clay loam & 44.80 & 22.40 & 31.71 & 8.3 & 0.97 & 9.87 & 2.16 \\
\hline Cations (me/L) & \multicolumn{7}{|c|}{ Anions (me/L) } \\
\hline $\mathrm{Na}$ & $\mathrm{K}$ & $\mathrm{Ca}$ & $\mathrm{Mg}$ & $\mathrm{CO}_{3}$ & $\mathrm{HCO}_{3}$ & $\mathrm{Cl}$ & $\mathrm{SO}_{4}$ \\
\hline 4.75 & 0.31 & 2.11 & 2.05 & 0 & 1.34 & 4.62 & 3.26 \\
\hline
\end{tabular}


Table 3 Germination rates and plant length as affected by water salinity in clay soil.

\begin{tabular}{|c|c|c|c|c|c|c|c|c|c|}
\hline \multirow{2}{*}{ Barley cultivars } & \multirow{2}{*}{$\begin{array}{l}\text { Water salinity } \\
(\mathrm{dS} / \mathrm{m})\end{array}$} & \multicolumn{3}{|c|}{ Number of germinated seeds at } & \multicolumn{2}{|c|}{ Plant length (cm/plant) } & \multirow{2}{*}{$\begin{array}{l}\text { Root:Shoot } \\
\text { ratio }\end{array}$} & \multicolumn{2}{|c|}{ Germination } \\
\hline & & $3 \mathrm{~d}$ & $5 \mathrm{~d}$ & $7 \mathrm{~d}$ & Root & Shoot & & rate & $\%$ \\
\hline \multirow{5}{*}{ Giza 123} & 0.31 & 8.0 & 9.5 & 9.5 & 7.83 & 8.75 & 89.3 & 5.92 & 95.0 \\
\hline & 3.21 & 4.7 & 9.0 & 9.5 & 7.17 & 9.60 & 75.2 & 4.71 & 95.0 \\
\hline & 5.74 & 2.0 & 8.0 & 9.0 & 6.17 & 7.00 & 88.2 & 3.55 & 90.0 \\
\hline & 8.28 & 1.7 & 6.5 & 9.0 & 6.17 & 7.75 & 79.8 & 3.14 & 90.0 \\
\hline & 12.86 & 0.7 & 4.0 & 7.3 & 5.50 & 5.90 & 94.8 & 2.07 & 73.3 \\
\hline \multirow{5}{*}{ Giza 124} & 0.31 & 7.5 & 9.5 & 10.0 & 6.67 & 9.10 & 73.4 & 5.83 & 100.0 \\
\hline & 3.21 & 4.5 & 8.5 & 10.0 & 4.83 & 7.45 & 65.3 & 4.63 & 100.0 \\
\hline & 5.74 & 4.0 & 8.0 & 9.5 & 6.00 & 6.50 & 100.4 & 4.29 & 95.0 \\
\hline & 8.28 & 4.0 & 7.0 & 9.0 & 5.67 & 5.75 & 98.8 & 4.02 & 90.0 \\
\hline & 12.86 & 2.0 & 6.0 & 7.5 & 6.50 & 8.70 & 74.3 & 2.94 & 75.0 \\
\hline \multirow{5}{*}{ Giza 125} & 0.31 & 8.0 & 9.7 & 10.0 & 7.67 & 9.25 & 100.8 & 6.03 & 100.0 \\
\hline & 3.21 & 9.5 & 9.0 & 9.0 & 7.00 & 8.50 & 82.5 & 6.25 & 90.0 \\
\hline & 5.74 & 7.0 & 8.0 & 7.5 & 6.17 & 8.42 & 72.5 & 5.00 & 75.0 \\
\hline & 8.28 & 5.0 & 6.5 & 6.3 & 5.17 & 6.75 & 78.0 & 3.87 & 63.3 \\
\hline & 12.86 & 2.0 & 3.5 & 4.5 & 4.67 & 4.75 & 107.4 & 2.01 & 45.0 \\
\hline \multirow{5}{*}{ Giza 126} & 0.31 & 10.0 & 10.0 & 10.0 & 8.83 & 12.50 & 72.2 & 6.76 & 100.0 \\
\hline & 3.21 & 9.5 & 10.0 & 9.7 & 8.50 & 10.10 & 85.4 & 6.55 & 96.7 \\
\hline & 5.74 & 8.0 & 9.7 & 9.3 & 7.50 & 8.00 & 94.4 & 5.93 & 93.3 \\
\hline & 8.28 & 7.0 & 9.0 & 9.0 & 6.13 & 9.50 & 64.5 & 5.42 & 90.0 \\
\hline & 12.86 & 6.5 & 6.5 & 8.5 & 4.07 & 11.75 & 34.7 & 4.68 & 85.0 \\
\hline \multirow{5}{*}{ Giza 127} & 0.31 & 10.0 & 10.0 & 10.0 & 5.83 & 12.75 & 47.0 & 6.76 & 100.0 \\
\hline & 3.21 & 8.5 & 10.0 & 10.0 & 6.17 & 10.00 & 61.6 & 6.26 & 100.0 \\
\hline & 5.74 & 7.5 & 10.0 & 9.0 & 5.50 & 9.30 & 59.6 & 5.79 & 90.0 \\
\hline & 8.28 & 7.3 & 9.0 & 7.5 & 4.50 & 9.38 & 48.0 & 5.32 & 75.0 \\
\hline & 12.86 & 1.5 & 7.0 & 7.0 & 3.07 & 8.67 & 36.3 & 2.90 & 70.0 \\
\hline \multirow{5}{*}{ Giza 129} & 0.31 & 9.5 & 10.0 & 10.0 & 8.33 & 14.30 & 58.6 & 6.60 & 100.0 \\
\hline & 3.21 & 7.5 & 9.5 & 10.0 & 7.33 & 13.00 & 56.2 & 5.83 & 100.0 \\
\hline & 5.74 & 6.5 & 9.0 & 9.0 & 7.83 & 11.75 & 66.2 & 5.25 & 90.0 \\
\hline & 8.28 & 5.0 & 7.5 & 8.0 & 6.50 & 11.67 & 54.8 & 4.31 & 80.0 \\
\hline & 12.86 & 8.0 & 7.0 & 9.5 & 7.50 & 10.00 & 75.8 & 5.42 & 95.0 \\
\hline \multirow{5}{*}{ Giza 130} & 0.31 & 9.0 & 10.0 & 10.0 & 11.00 & 13.50 & 81.1 & 6.43 & 100.0 \\
\hline & 3.21 & 8.5 & 9.5 & 9.5 & 10.67 & 11.80 & 93.9 & 6.09 & 95.0 \\
\hline & 5.74 & 5.0 & 9.5 & 9.5 & 7.70 & 9.25 & 84.8 & 4.92 & 95.0 \\
\hline & 8.28 & 5.5 & 8.0 & 9.0 & 7.33 & 8.05 & 91.1 & 4.72 & 90.0 \\
\hline & 12.86 & 5.5 & 7.3 & 8.5 & 5.17 & 6.85 & 75.4 & 4.51 & 85.0 \\
\hline \multirow{5}{*}{ Giza 134} & 0.31 & 6.5 & 9.5 & 9.5 & 9.67 & 13.80 & 70.0 & 5.42 & 95.0 \\
\hline & 3.21 & 2.5 & 9.5 & 9.5 & 7.67 & 10.00 & 76.7 & 4.09 & 95.0 \\
\hline & 5.74 & 3.5 & 9.5 & 9.5 & 7.50 & 10.75 & 70.2 & 4.42 & 95.0 \\
\hline & 8.28 & 3.5 & 7.5 & 8.0 & 7.00 & 9.90 & 70.8 & 3.81 & 80.0 \\
\hline & 12.86 & 3.0 & 7.5 & 7.0 & 6.33 & 7.50 & 90.6 & 3.50 & 70.0 \\
\hline \multirow{5}{*}{ Giza 135} & 0.31 & 9.5 & 10.0 & 10.0 & 6.83 & 14.50 & 46.8 & 6.60 & 100.0 \\
\hline & 3.21 & 9.0 & 9.5 & 10.0 & 5.83 & 12.80 & 45.7 & 6.33 & 100.0 \\
\hline & 5.74 & 8.0 & 9.5 & 9.5 & 5.50 & 12.50 & 44.1 & 5.92 & 95.0 \\
\hline & 8.28 & 5.5 & 9.5 & 8.3 & 4.67 & 6.85 & 67.9 & 4.92 & 83.3 \\
\hline & 12.86 & 5.0 & 7.0 & 7.5 & 2.67 & 6.75 & 39.9 & 4.14 & 75.0 \\
\hline
\end{tabular}


(Table 3 continued)

\begin{tabular}{|c|c|c|c|c|c|c|c|c|c|}
\hline \multirow{2}{*}{ Barley cultivars } & \multirow{2}{*}{$\begin{array}{l}\text { Water salinity } \\
(\mathrm{dS} / \mathrm{m})\end{array}$} & \multicolumn{3}{|c|}{ Number of germinated seeds at } & \multicolumn{2}{|c|}{ Plant length (cm/plant) } & \multirow{2}{*}{$\begin{array}{l}\text { Root:Shoot } \\
\text { ratio }\end{array}$} & \multicolumn{2}{|c|}{ Germination } \\
\hline & & $3 \mathrm{~d}$ & $5 \mathrm{~d}$ & $7 \mathrm{~d}$ & Root & Shoot & & rate & $\%$ \\
\hline \multirow{5}{*}{ Giza 2000} & 0.31 & 10.0 & 10.0 & 10.0 & 9.33 & 15.50 & 60.3 & 6.76 & 100.0 \\
\hline & 3.21 & 7.3 & 10.0 & 10.0 & 6.67 & 9.50 & 70.2 & 5.87 & 100.0 \\
\hline & 5.74 & 5.5 & 9.5 & 9.5 & 5.83 & 8.55 & 68.7 & 5.09 & 95.0 \\
\hline & 8.28 & 1.5 & 8.7 & 9.0 & 4.83 & 8.25 & 58.6 & 3.52 & 90.0 \\
\hline & 12.86 & 0.5 & 6.5 & 8.0 & 2.83 & 4.25 & 66.8 & 2.61 & 80.0 \\
\hline \multicolumn{10}{|c|}{ Least significant difference (LSD) (0.05) } \\
\hline \multicolumn{2}{|c|}{ Barley cultivars (V) } & 0.91 & 0.72 & 0.53 & 1.00 & 0.65 & 17.03 & 1.42 & 3.72 \\
\hline \multicolumn{2}{|c|}{ Salinity levels $(\mathrm{T})$} & 0.64 & 0.46 & 0.37 & 0.71 & 0.62 & 13.63 & 0.57 & 5.62 \\
\hline \multicolumn{2}{|l|}{$\left(\mathrm{V}^{*} \mathrm{~T}\right)$} & 2.03 & 1.44 & 1.16 & 2.24 & 1.97 & 43.10 & 2.51 & 10.07 \\
\hline
\end{tabular}

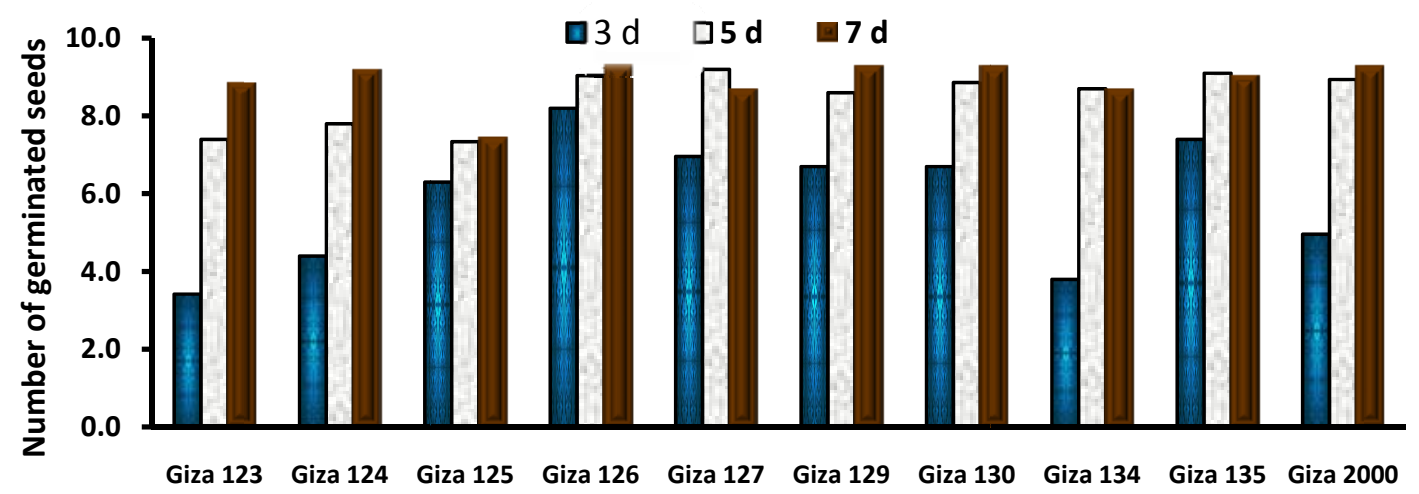

Fig. 1 Barley cultivar differences in germination speed.

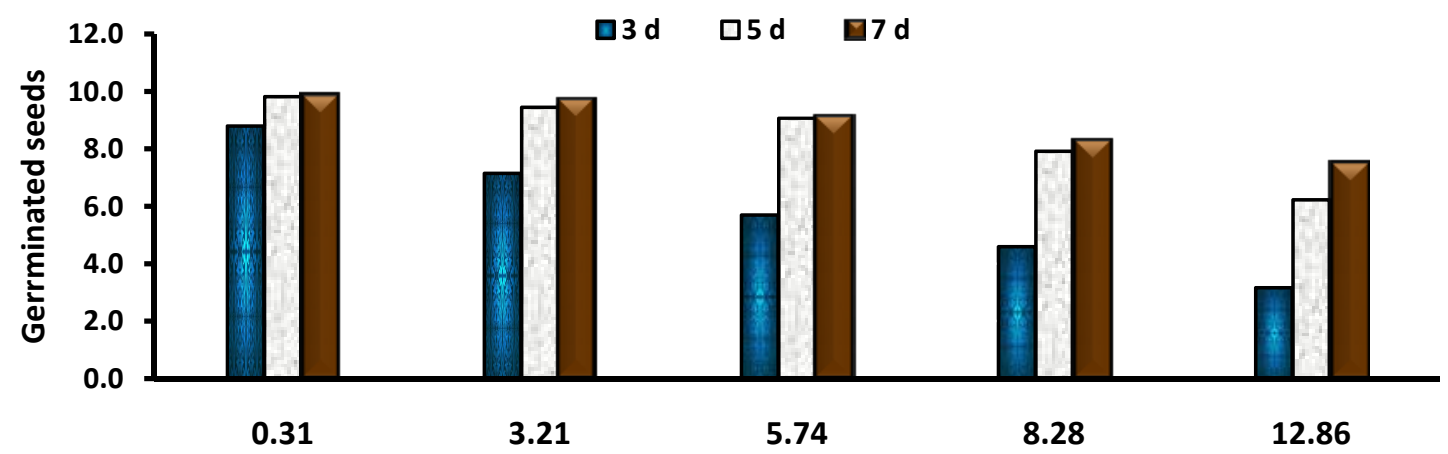

Fig. 2 Effect of water salinity (dS/m) on germinated seed number.

germinated seeds values. But after 7 d Giza 126, 129, 130 and 2000 have got the highest values (9.3) followed by Giza 124 (9.2). Regardless barley cultivars, water salinity inhibited the germinated seeds at different periods where increasing water salinity associated with decreasing a number of the germinated seeds. It is clear the lowest values of germinated seeds noticed at $8.28 \mathrm{dS} / \mathrm{m}$ and 12.86
$\mathrm{dS} / \mathrm{m}$ and the highest values were attained under fresh water $(0.31 \mathrm{dS} / \mathrm{m})$. Meanwhile, values of the germinated seeds after $3 \mathrm{~d}$ were lower than that of $5 \mathrm{~d}$ and $7 \mathrm{~d}$, respectively.

The rate of decrease of the germinated seeds after the examined periods was calculated and could be written as follows: $18.8 \%, 35.2 \%, 47.4 \%$ and $64.0 \%$ at $3 \mathrm{~d}, 3.8 \%, 7.6 \%, 19.3 \%$ and $36.3 \%$ after $5 \mathrm{~d}$ and 
$1.8 \%, 7.8 \%, 16.1 \%$ and $23.9 \%$ after $7 \mathrm{~d}$. It is worthy to mention that the percentage of the reduction in germinated seeds increased after $3 \mathrm{~d}$ than the other two studied periods from 2-6 folds. Higher level of salt stress inhibits the germination of seeds while lower level of salinity induces a state of dormancy [7]. Additionally, increasing salt stress from $8.28 \mathrm{dS} / \mathrm{m}$ and $12.86 \mathrm{dS} / \mathrm{m}$ increased the time needed for complete germination which affect indirectly on the consequence of different following growth period.

\subsection{Root and Shoot Length}

Regarding to the root and shoot length, data in Table 3 indicated that the highest values were obtained at fresh water under all tested barley cultivars. Same trend was obtained for shoot length except Giza $123(3.21 \mathrm{dS} / \mathrm{m})$. Also, data observed that the highest values of root and shoot length were recorded at Giza 130 followed by Giza 2000 for root length and for shoot length, Giza $2000(15.5 \mathrm{~cm})$ and Giza 135 (14.5 $\mathrm{cm})$. With respect to the effect of investigated barley cultivars on the root and shoot length, results pointed out that Giza 129, 130 and 134 were superior for roots and Giza 135, 134 and 126 was the highest for shoot. Also, the lowest values of the root and shoot length were recorded at Giza $135(5.1 \mathrm{~cm})$ for root length and Giza 124 and Giza $125(9.5 \mathrm{~cm})$ for shoot. The obtained data revealed that increased salinity in water combined with decreasing in root and shoot length where the highest values scored at fresh water and the lowest ones were recorded at highly water salinity (12.86 dS/m).

Water salinity relative to the control (fresh water), data presented in Table 3 showed that the reduction with increasing salinity were $12.4 \%, 19.9 \%, 29.3 \%$, $41.3 \%$ and $17.1 \%, 25.8 \%, 32.4 \%, 38.4 \%$ for root and shoot length, respectively. Root:shoot percentage did not take a clear trend where the highest values attained at Giza $124(8.28 \mathrm{dS} / \mathrm{m})$, Giza $125(12.86 \mathrm{dS} / \mathrm{m})$ and Giza $124(5.74 \mathrm{dS} / \mathrm{m})$ and the lowest values were recorded at Giza 135 in all water salinity, except 12.86
$\mathrm{dS} / \mathrm{m}$. With respect to the examined barley cultivars effect on the percentage between root and shoot length, data revealed that the superior cultivars could rank as follow in descending order: Giza $130>$ Giza $125>$ Giza $123>$ Giza 124 and the lowest percentage was singled out at Giza 127.

According to the effect of water salinity on the root to shoot percentage, results indicated that increased salinity did not give a clear trend; however the highest and lowest percentages were recorded at $8.28 \mathrm{dS} / \mathrm{m}$ (71.1\%) and $12.86 \mathrm{dS} / \mathrm{m}$ (66.2\%), respectively. Also, it is worthy to mention that these percentages were increased by $4.1 \%, 8.7 \%, 4.8 \%$ and $-2.6 \%$ at water salinity $3.21,5.74,8.28$ and $12.86 \mathrm{dS} / \mathrm{m}$ relative to the control, respectively. Salinity stress adversely affects almost all stages of growth and development, such as germination, growth and vigor of seedling, vegetative growth, flowering and fruit set and ultimately causing diminished economic yield and also quality of products. Seed germination is one of the most important phases in the life cycle of plant and is highly responsive to existing environment [20].

\subsection{Germination Rate and Percentage}

Data in Table 3 noted that the maximum which obtained at fresh water and examined barley cultivars Giza 126, 127 and 2000 that could be considered the superior ones. Same trend was resulted in case of germination percentage where Giza 127, 125, 135 and 2000 more tolerant for salinity followed by Giza 134 . Also, it is clear to point out that high water salinity had a negative effect on the both germination rate and percentage. The lowest values were recorded at water salinity especially $12.86 \mathrm{dS} / \mathrm{m}$ and barley cultivars Giza 123, 125 and 2000. Regarding to the effect of examined barley cultivars on the germination rate and percentage, data in Table 3 and Fig. 2 revealed that the highest GR was attained at Giza 126 (5.9), Giza 135 (5.6) and Giza 129 (5.5) and got the highest germination percentage but exceed Giza 2000 [21]. Conducted germination and pot experiments were 
conducted to study the influence of irrigation water salinity on yield and chemical composition of wheat in sandy and calcareous soil. Irrigation water salinity levels were 0.43 (control), 4.85, 6.60 and $8.86 \mathrm{dS} / \mathrm{m}$, respectively. Results concluded that, the lower germination percentage and rate and mean daily germination in calcareous soil at any salinity level compared to sandy soil.

Water salinity had a negative effect on the germination rate and percentage, where the highest and lowest values were recorded at $0.31 \mathrm{dS} / \mathrm{m}$ (fresh water) and $12.86 \mathrm{dS} / \mathrm{m}$, respectively (Fig. 3). Also, it is worthy to state that till $5.24 \mathrm{dS} / \mathrm{m}$, germination rate and percentage are still high which represented that barely cultivars were more tolerant to water salinity.

In addition that the percentage of reduction relative to the increase water salinity were $10.3 \%, 20.5 \%, 31.8 \%$ and $44.9 \%$ for germination rate and $1.8 \%, 7.7 \%, 16.0 \%$ and $23.9 \%$ for germination percentage at water salinity $3.21,5.74,8.28$ and $12.86 \mathrm{dS} / \mathrm{m}$ as compared with control (fresh water), respectively (Fig. 4).

\subsection{Fresh and Dry Weight}

Table 4 and Figs. 5 and 6 represented fresh and dry weight and TWC (\%) of root and shoot as affected by examined barley cultivars and water salinity.

Usually, there is a markedly decrease in the obtained value with increasing salinity among water salinity treatments in each barely cultivars. Also, the highest were recorded at high water salinity. There were two barley cultivars (Giza 134 and Giza 2000) that gained the highest value of fresh weight root and shoot. Whereas, Giza 126 had no plants germinated at $12.86(\mathrm{dS} / \mathrm{m})$. Similar trend was attained in case of dry

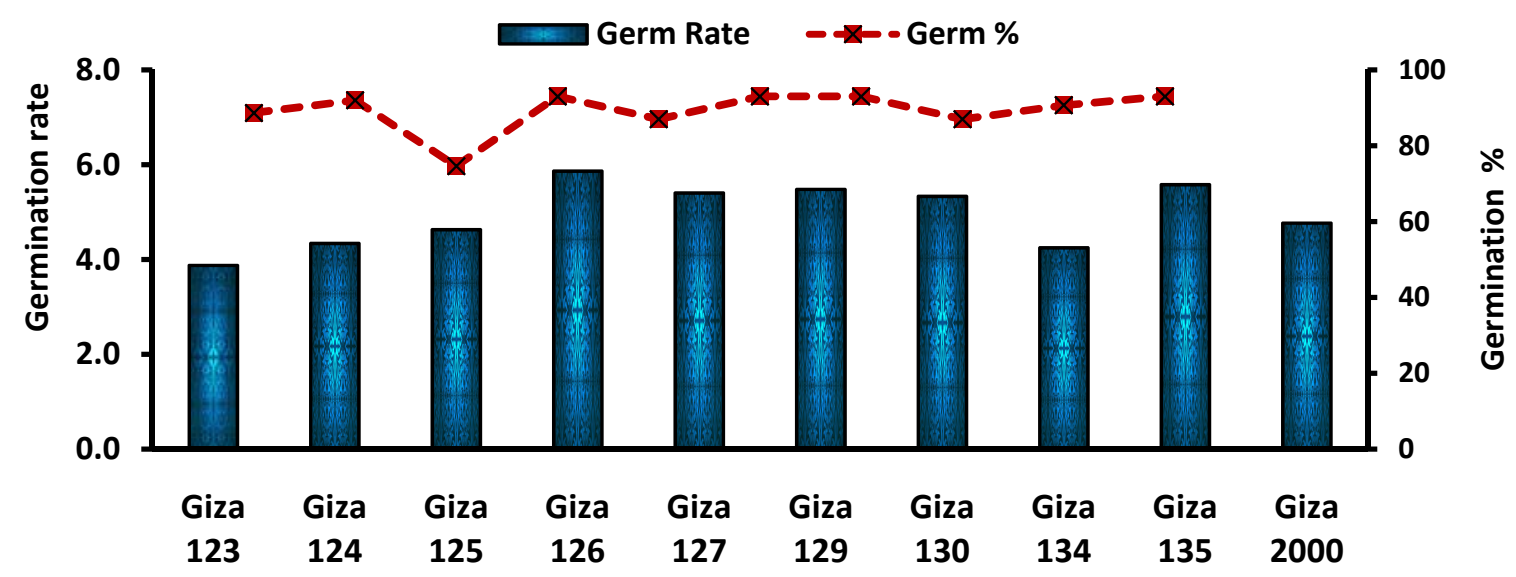

Fig. 3 Barley cultivar differences in germination rate and percentage.

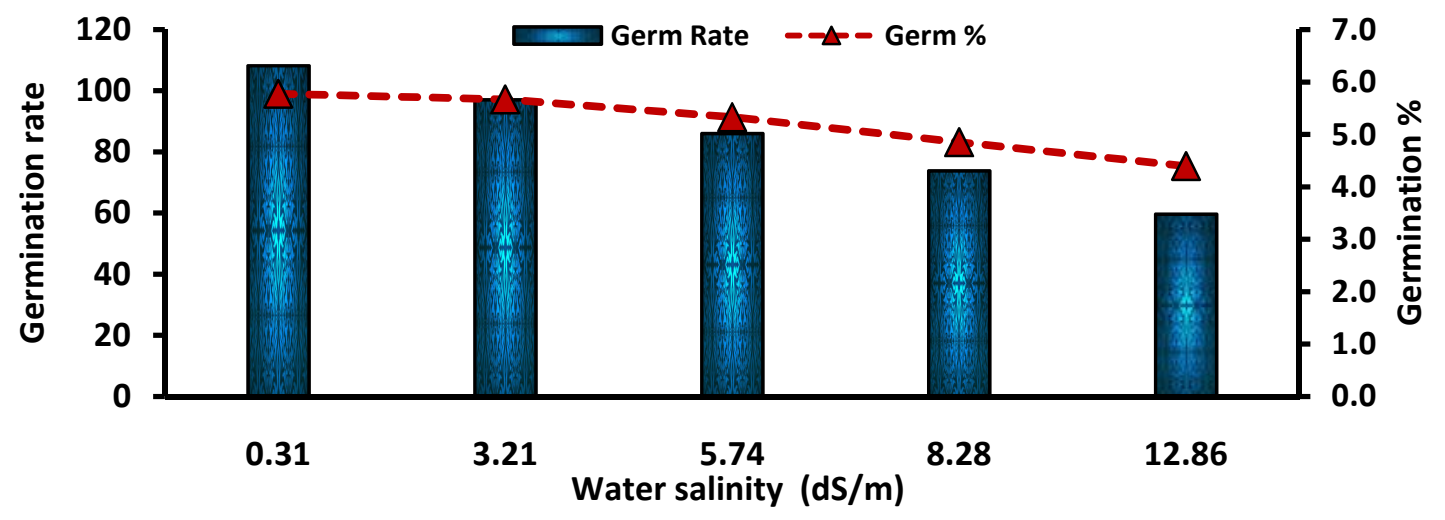

Fig. 4 Effect of water salinity on germination percentage and rate of barley cultivars. 
of Egyptian Barley Cultivars

Table 4 Root and shoot weight and tissue water content (TWC) as affected by irrigation water salinity.

\begin{tabular}{|c|c|c|c|c|c|c|c|c|}
\hline \multirow{2}{*}{$\begin{array}{l}\text { Barley } \\
\text { cultivars }\end{array}$} & \multirow{2}{*}{$\begin{array}{l}\text { Water salinity } \\
(\mathrm{dS} / \mathrm{m})\end{array}$} & \multicolumn{2}{|c|}{ Fresh weight (mg/plant) } & \multicolumn{2}{|c|}{ Dry weight (mg/plant) } & \multicolumn{2}{|c|}{ TWC (\%) } & \multirow{2}{*}{$\begin{array}{l}\text { Seedling vigor } \\
\text { index }\end{array}$} \\
\hline & & Root & Shoot & Root & Shoot & Root & Shoot & \\
\hline \multirow{5}{*}{ Giza 123} & 0.31 & 98.1 & 196.2 & 17.3 & 15.45 & 82.39 & 92.1 & 15.75 \\
\hline & 3.21 & 84.2 & 168.4 & 12.9 & 13.19 & 84.64 & 92.2 & 15.93 \\
\hline & 5.74 & 76.1 & 152.2 & 9.1 & 8.91 & 88.00 & 94.1 & 11.85 \\
\hline & 8.28 & 52.2 & 104.4 & 6.4 & 5.99 & 87.82 & 94.3 & 12.53 \\
\hline & 12.86 & 51.7 & 103.3 & 6.0 & 6.35 & 58.98 & 62.6 & 5.24 \\
\hline \multirow{5}{*}{ Giza 124} & 0.31 & 79.7 & 159.3 & 11.9 & 11.63 & 85.03 & 92.7 & 15.77 \\
\hline & 3.21 & 78.8 & 157.6 & 12.1 & 10.67 & 84.64 & 93.2 & 12.28 \\
\hline & 5.74 & 72.0 & 144.0 & 8.6 & 9.54 & 88.00 & 93.4 & 11.88 \\
\hline & 8.28 & 62.7 & 125.3 & 8.7 & 8.12 & 86.13 & 93.5 & 10.28 \\
\hline & 12.86 & 48.7 & 97.3 & 7.3 & 5.98 & 0.00 & 0.0 & 11.40 \\
\hline \multirow{5}{*}{ Giza 125} & 0.31 & 86.7 & 170.0 & 18.5 & 11.56 & 78.63 & 93.2 & 16.92 \\
\hline & 3.21 & 77.0 & 167.3 & 11.8 & 12.15 & 84.64 & 92.7 & 13.95 \\
\hline & 5.74 & 71.8 & 143.6 & 9.8 & 7.94 & 86.36 & 94.5 & 10.94 \\
\hline & 8.28 & 70.8 & 136.4 & 8.6 & 7.82 & 87.82 & 94.3 & 7.55 \\
\hline & 12.86 & 68.2 & 126.9 & 12.0 & 7.79 & 27.45 & 31.3 & 4.24 \\
\hline \multirow{5}{*}{ Giza 126} & 0.31 & 94.1 & 184.9 & 16.6 & 17.28 & 82.39 & 90.7 & 21.33 \\
\hline & 3.21 & 87.9 & 175.8 & 19.5 & 13.76 & 77.83 & 92.2 & 17.98 \\
\hline & 5.74 & 81.4 & 162.9 & 12.9 & 10.12 & 84.20 & 93.8 & 14.47 \\
\hline & 8.28 & 63.2 & 126.4 & 7.7 & 7.25 & 87.82 & 94.3 & 14.07 \\
\hline & 12.86 & 48.2 & 101.1 & 7.1 & 6.5 & 88.60 & 93.6 & 13.44 \\
\hline \multirow{5}{*}{ Giza 127} & 0.31 & 91.1 & 182.2 & 16.0 & 14.35 & 82.39 & 92.1 & 18.58 \\
\hline & 3.21 & 80.0 & 160.0 & 8.4 & 12.53 & 89.48 & 92.2 & 16.17 \\
\hline & 5.74 & 72.2 & 144.4 & 8.7 & 8.45 & 88.00 & 94.1 & 13.32 \\
\hline & 8.28 & 68.8 & 137.6 & 8.4 & 7.89 & 87.82 & 94.3 & 10.41 \\
\hline & 12.86 & 63.6 & 127.1 & 9.5 & 7.81 & 28.34 & 31.3 & 8.21 \\
\hline \multirow{5}{*}{ Giza 129} & 0.31 & 86.2 & 172.4 & 15.2 & 12.59 & 82.39 & 92.7 & 22.63 \\
\hline & 3.21 & 81.1 & 162.2 & 12.5 & 10.98 & 84.64 & 93.2 & 20.33 \\
\hline & 5.74 & 68.6 & 137.1 & 8.2 & 9.09 & 88.00 & 93.4 & 17.63 \\
\hline & 8.28 & 62.2 & 124.4 & 7.6 & 8.06 & 87.82 & 93.5 & 14.53 \\
\hline & 12.86 & 58.8 & 117.6 & 6.8 & 7.22 & 58.98 & 62.6 & 16.63 \\
\hline \multirow{5}{*}{ Giza 130} & 0.31 & 90.0 & 180.0 & 13.5 & 12.24 & 85.03 & 93.2 & 24.50 \\
\hline & 3.21 & 87.3 & 174.7 & 13.4 & 12.68 & 84.64 & 92.7 & 21.34 \\
\hline & 5.74 & 71.1 & 142.2 & 8.5 & 7.86 & 58.66 & 63.0 & 16.10 \\
\hline & 8.28 & 69.8 & 139.6 & 9.7 & 8.00 & 28.71 & 31.4 & 13.85 \\
\hline & 12.86 & 48.3 & 96.7 & 7.2 & 5.94 & 0.00 & 0.0 & 10.21 \\
\hline \multirow{5}{*}{ Giza 134} & 0.31 & 104.9 & 209.8 & 22.4 & 19.61 & 78.63 & 90.7 & 22.29 \\
\hline & 3.21 & 78.9 & 157.8 & 12.1 & 12.36 & 84.64 & 92.2 & 16.78 \\
\hline & 5.74 & 66.1 & 142.4 & 9.0 & 8.85 & 86.36 & 93.8 & 17.34 \\
\hline & 8.28 & 71.2 & 132.2 & 8.7 & 7.58 & 87.82 & 94.3 & 13.52 \\
\hline & 12.86 & 63.4 & 126.9 & 11.2 & 8.89 & 82.36 & 93.0 & 9.68 \\
\hline \multirow{5}{*}{ Giza 135} & 0.31 & 62.4 & 144.9 & 11.0 & 9.86 & 82.39 & 93.2 & 21.33 \\
\hline & 3.21 & 72.4 & 132.9 & 16.1 & 9.65 & 77.83 & 92.7 & 18.63 \\
\hline & 5.74 & 66.4 & 124.9 & 10.5 & 6.90 & 84.20 & 94.5 & 17.10 \\
\hline & 8.28 & 46.0 & 104.4 & 5.6 & 5.99 & 87.82 & 94.3 & 9.60 \\
\hline & 12.86 & 52.2 & 92.0 & 6.0 & 5.65 & 88.47 & 93.9 & 7.06 \\
\hline
\end{tabular}


(Table 4 continued)

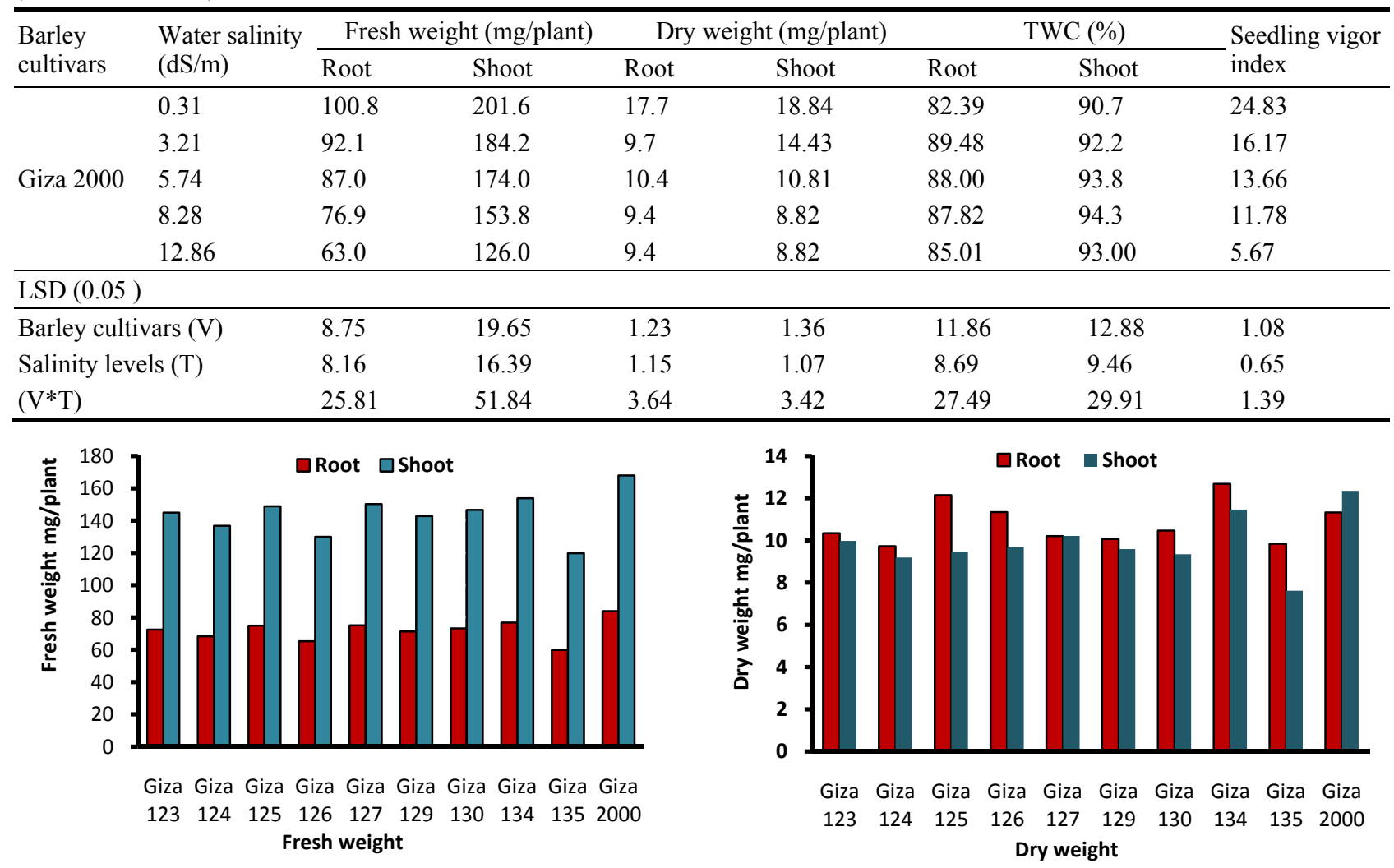

Fig. 5 Effect of water salinity on fresh and dry weight of barley cultivars.
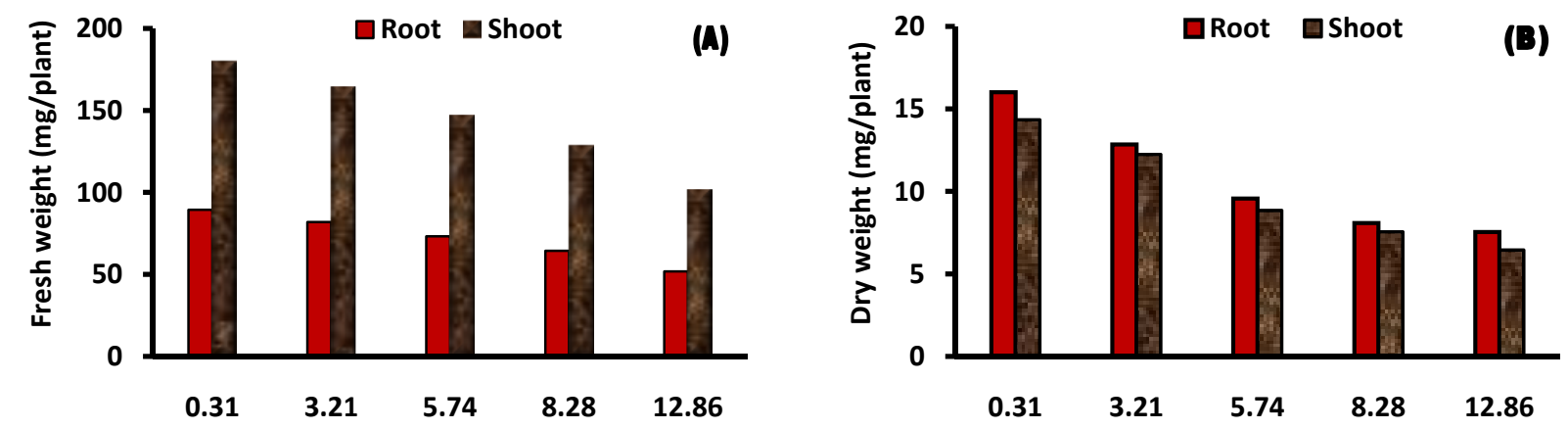

Fig. 6 Effect of water salinity (dS/m) on fresh weight (A) and dry weight (B) of barley.

weight of root and shoot, where Giza 134 and Giza 2000 were the best ones.

Regarding to the examined barley cultivars effect on the fresh weight and dry weight of root and shoot, data on hand indicated that Giza 2000 was the superior variety whom scored the highest value followed by Giza 125, 127 and 134 in case of fresh weight of root and shoot, respectively. In case of dry weight of root, Giza 134 followed by Giza 125 and Giza 2000 followed by Giza 134 for shoot dry weight.
Regarding to the effect of water salinity on the fresh weight and dry weight of root and shoot, data indicated that there was a markedly decrease in fresh weight and dry weight of root and shoot with increasing salinity in water and the reduction under shoot is more than root and the opposite was true in case of dry weight. It could summarize the reduction percentage resulted from increasing water salinity as follows: $8.3 \%, 18.0 \%, 28.0 \%, 42.1 \%$ and $8.9 \%$, $18.5 \%, 28.7 \%, 43.7 \%$ for fresh weight of root and 
shoot at $3.21,5.74,8.28$ and $12.86 \mathrm{dS} / \mathrm{m}$ as compared with control treatment, respectively.

In case of dry weight the percentage of reduction were $19.7 \%, 40.2 \%, 49.5 \%, 52.9 \%$ and $14.7 \%, 38.3 \%$, $43.3 \%, 55.1 \%$ for root and shoot in same sequences. Naseer et al. [22] reported that the germination percentage, root and shoot length and fresh and dry weights were decreased in barley cultivars by increasing of salinity levels.

\subsection{Tissue Water Content}

The TWC in root and shoot of barley cultivars severely was affected by increasing water salinity. These values were little large for Giza 2000 and Giza $127(3.21 \mathrm{dS} / \mathrm{m})$ followed by water salinity $5.74 \mathrm{dS} / \mathrm{m}$ in the same barley of root. But in case of shoot data showed that the highest values were attained in cultivars Giza 125, 127 and 129 with highly water salinity $5.74 \mathrm{dS} / \mathrm{m}$ and $8.28 \mathrm{dS} / \mathrm{m}$. The lowest values of TWC recorded at $12.86 \mathrm{dS} / \mathrm{m}$ water salinity in all examined barley cultivars.

Concerning to the effect of examined barley cultivars on the TWC for root and shoot, data presented in Table 4 and Figs. 7 and 8 illustrated that Giza 2000 followed by Giza 134 and Giza 135 were the best for root and Giza 135, followed by Giza 134 and Giza 2000 for shoot were more pronounced effect barley cultivars, while the lowest ones were Giza 130 for root and shoot. In case of the effect of the investigated water salinity, data cleared that progressively decreased in TWC for root and shoot with increasing water salinity. The maximum values were attained in water salinity $3.21 \mathrm{dS} / \mathrm{m}$ and 5.74 $\mathrm{dS} / \mathrm{m}$ for root and $0.31 \mathrm{dS} / \mathrm{m}, 92.55 \%$ for shoot. Also, it noticed that the change in TWC for root and shoot relative to the increase water salinity were expressed in percentage $-2.5 \%,-2.2 \%, 0.5 \%, 47.7 \%$ and $-0.5 \%$, $1.4 \%, 4.6 \%, 49.2 \%$, respectively.

With respect to the examined barley cultivars effect on the TWC, the highest number scored at Giza 129 $(21.2 \%)$ and Giza 134 (20.7\%) while the lowest one was recorded at Giza 124 (14.8\%). The differences between the obtained highest relative to the lowest one data found that Giza 129 and Giza 134 increased by about $43 \%$ and $40 \%$, respectively. Also, the results of the TWC showed that the effect of water salinity was significantly at $1 \%$. Only fresh water gave the highest value of TWC for root and shoot and water salinity at $12.86 \mathrm{dS} / \mathrm{m}$ gave the lowest one. Water salinity had an adverse effect on the TWC. The rates of decrease in percentage in tissue water content were 14\%, 17\%, 19\% and $20 \%$ relative to the control (fresh water).

\subsection{Seedling Vigor Index}

The SVI was strongly affected by both examined barley cultivars and water salinity. Data in Table 4 and Figs. 9 and 10 showed that the cultivars Giza 2000, 134 and 126 gained the highest value in descending order $24.8 \%, 24.7 \%$ and $21.5 \%$ as compared with control (fresh water). But mostly the lowest values (8.9\% (Giza 2000), 12.3\% (Giza 124) and $12.6 \%$ (Giza 135)) were highly correlated with water salinity. It is well established that salt stress has negative correlation with seed germination and SVI [23].

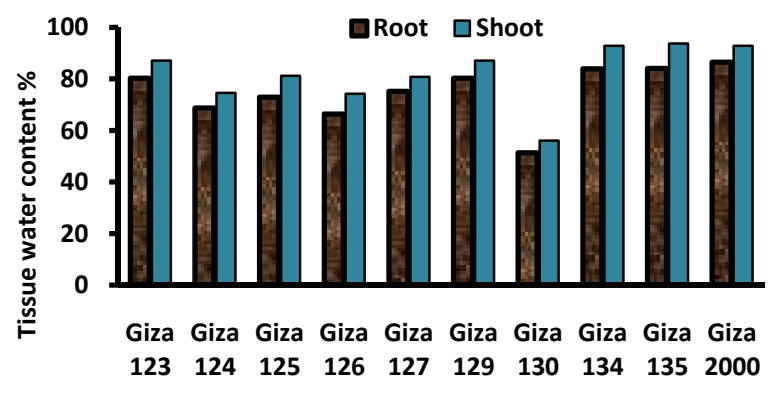

Fig. 7 Barley cultivar differences in tissue water content.

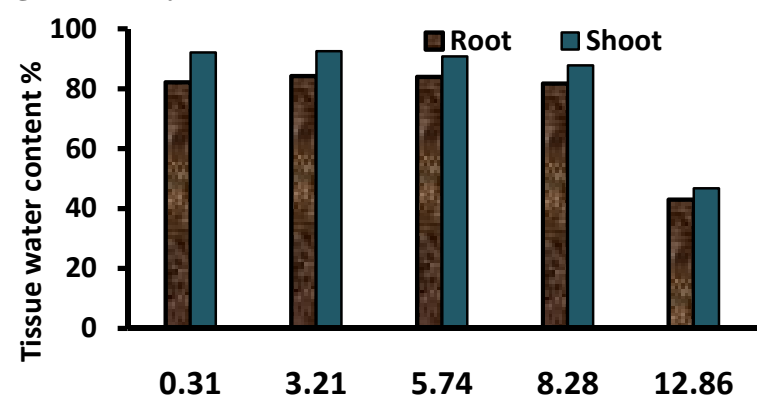

Fig. 8 Effect of water salinity on tissue water content. 


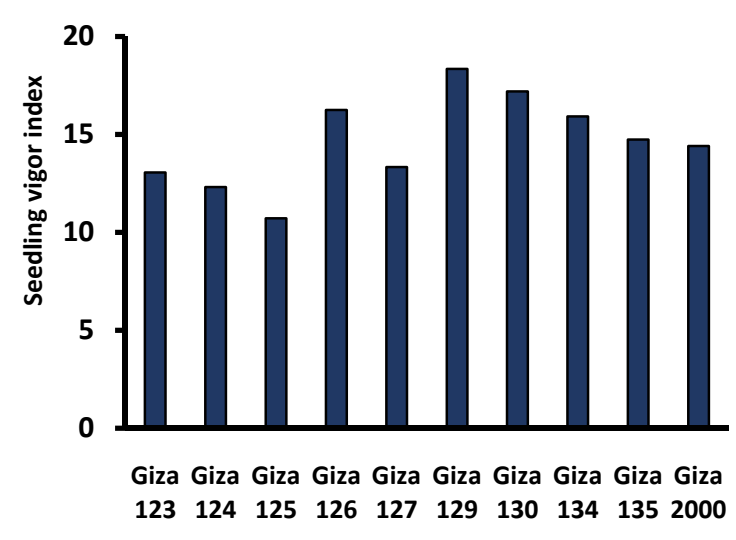

Fig. 9 Barley cultivar differences in seedling vigor index.

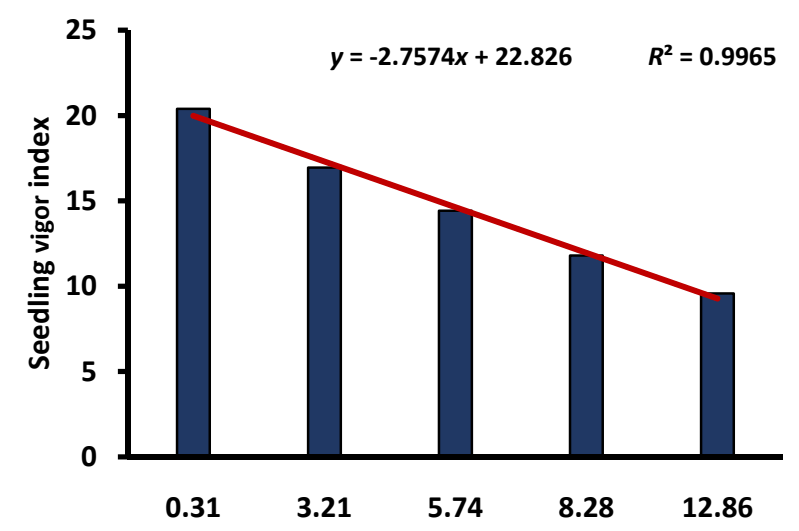

Fig. 10 Relation between water salinity and seedling vigor index.

\subsection{Correlation Analysis}

It is worthy to mention that there were highly positive correlation coefficients between periods of germination and GR with $r$ values $0.963 * *, 0.855^{* *}$ and $0.742 * *$ and with germination percentage $0.571 *$, $0.802 * *$ and $0.998 * *$. Also, markedly positive correlation between SVI from side and fresh weight and dry weight for root and shoot were obtained with $r$ values $0.546^{*}, 0.573^{*}, 0.588^{*}$ and $0.647^{* *}$, respectively.

\subsection{SDS-PAGE Profile of Saline Irrigation Water of Barley Cultivars in Germination Stage}

Increased salt concentration caused a significant reduction in the vegetative growth of barley cultivars. Fresh and dry weights of sugar beet decreased significantly with increasing salt concentration in the growth medium. However, significant reduction was observed at high salinity levels. In this experiment the total soluble protein profile shows no significant difference between normal plant and stressed plant (Fig. 11) that may indicate to the positive effect of the clay soil as a reach nutrients soil comparing to sandy soil which was used in the previous salt stress experiment.

There was a decrease in the amount of total soluble protein content with the high salinity level (Fig. 11) in cultivar Giza 2000 even if it was showing high percentage of germination and dry matter content. Data

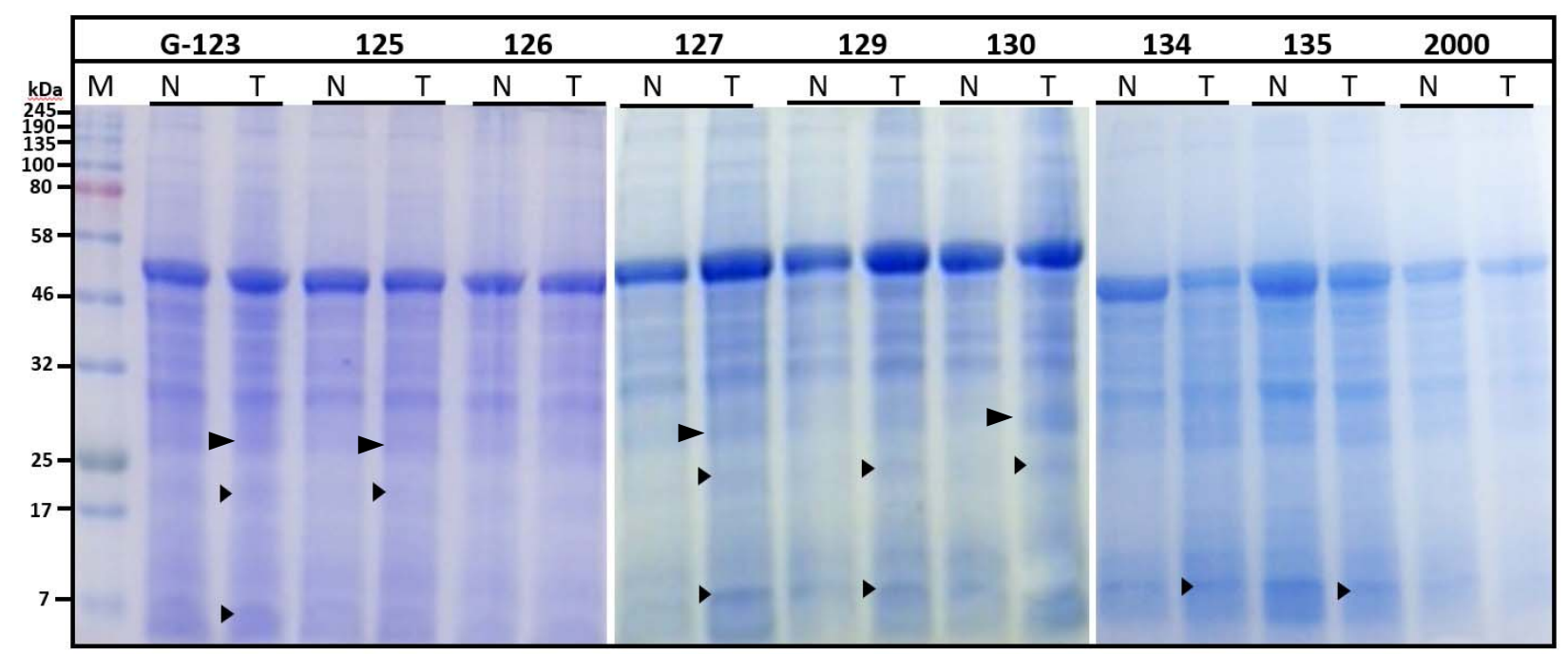

Fig. 11 SDS-PAGE banding patterns showing the total soluble proteins from the leaf tissue of tested nine barley genotypes, Giza 123, 125, 126, 127, 129, 130, 134, 135 and 2000 after $10 \mathrm{~d}$ of germination in clay soil watering with saline solution. First lane is protein marker; N: normal condition; T: treated with saline water. 
revealed a high intensity of $20 \mathrm{kDa}$ protein band in treated sample with saline water than the control sample especially the cultivars Giza 123, 125, 126, 127, 129 and 130. The $6 \mathrm{kDa}$ protein bands had the same increasing after salt stress in cultivars Giza 123, 127, 129, 134 and 135. The same protein band with 27 $\mathrm{kDa}$ was also get accumulated after stress treatment similar to the previous salt stress experiment, which may be related to the oxygen-evolving enhancer protein 2 (OEE2) associated with photo system II complex involved in photosynthesis activity under a biotic stress [24].

\section{Conclusions}

The ability of barley cultivars Giza 134 and Giza 2000 to grow under the high salinity of irrigation water was greater than the rest of the other cultivars. So, it could be recommended for farmer to be grown under saline irrigation water conditions.

\section{Acknowledgments}

The authors warmly thank the Agricultural Research in the Mediterranean Area 2 (ARIMNet 2) and Academy of Scientific Research and Technology (ASRT) and National Research Centre (NRC), Egypt who have funded this research work.

\section{References}

[1] Siddiqui, Z. S., Shaukat, S. S., and Zaman, A. U. 2006. "Alleviation of Salinity Induced Dormancy by Growth Regulators in Wheat Seeds." Turk. J. Bot. 30: 321-30.

[2] Kausar, F., Shahbaz, M., and Ashraf, M. 2013. "Protective Role of Foliar Applied Nitric Oxide in Triticum aestivum under Saline Stress.” Turk. J. Bot. 37: 1155-65.

[3] Munns, R. 2002. "Comparative Physiology of Salt and Water Stress." Plant Cell Environ. 25: 239-50.

[4] Hameed, M., Nawaz, T., Ashraf, M., Naz, N., Batool, R., Ahmad, M. S. A., and Riaz, A. 2013. "Physioanatomical Adaptations in Response to Salt Stress in Sporobolus arabicus (Poaceae) from the Salt Range, Pakistan." Turk. J. Bot. 37: 715-24.

[5] Emam, Y. 2011. Cereal Production. 4th edition. Shiraz, Iran: Shiraz University Press.
[6] Kaya, M. D., Okcu, G., Atak, M., Cikili, Y., and Kolsarici, O. 2006. "Seed Treatments to Overcome Salt and Drought Stress during Germination in Sunflower (Helianthus annuus L.).” Eur. J. Agro. 24: 291-5.

[7] Khan, M. A., and Weber, D. J. 2008. Ecophysiology of High Salinity Tolerant Plants (Tasks for Vegetation Science). 1st edition. Amsterdam: Springer.

[8] Gomes-Filho, E., Machado Lima, C. R. F., Costa, J. H., da Silva, A. C., da Guia Silva Lima, M., de Lacerda, C. F., and Prisco, J. T. 2008. "Cowpea Ribonuclease: Properties and Effect of NaCl-Salinity on Its Activation during Seed Germination and Seedling Establishment." Plant Cell Rep. 27: 147-57.

[9] Dantas, B. F., De Sa Ribeiro, L., and Aragao, C. A. 2007. "Germination, Initial Growth and Cotyledon Protein Content of Bean Cultivars under Salinity Stress." Rev. Bras. de Sementes 29: 106-10.

[10] Othman, Y., Al-Karaki, G., Al-Tawaha, A. R., and Al-Horani, A. 2006. "Variation in Germination and Ion Uptake in Barley Genotypes under Salinity Conditions." World J. Agric. Sci. 2: 11-5.

[11] Rasheed, R. 2009. "Salinity and Extreme Temperature Effects on Sprouting Buds of Sugarcane (Saccharum ficinarum L.): Some Histological and Biochemical Studies." Ph.D. thesis, Dept. of Botany, Univ. of Agriculture, Faisalabad, Pakistan.

[12] Wahid, A., Farooq, M., Basra, S. M. A., Rasul, E., and Siddique, K. H. M. 2011. "Germination of Seeds and Propagules under Salt Stress." In Handbook of Plant and Crop Stress, 3rd edition, edited by Pessarakli, M. Boca Raton: CRC Press, 321-37.

[13] Pirasteh-Anosheh, H., Sadeghi, H., and Emam, Y. 2011. "Chemical Priming with Urea and $\mathrm{KNO}_{3}$ Enhances Maize Hybrids (Zea mays L.) Seed Viability under Abiotic Stress.” J. Crop Sci. Biotech. 14: 289-95.

[14] Ashraf, M., Athar, H. R., Harris, P. J. C., and Kwon, T. R. 2008. "Some Prospective Strategies for Improving Crop Salt Tolerance." Adv. Agron. 97: 45-110.

[15] International Seed Testing Association (ISTA). 2008. International Rules for Seed Testing. Zurich: ISTA.

[16] Larkindale, J., and Huang, B. 2004. "Thermotolerance and Antioxidant Systems in Agrostis stolonifera: Involvement of Salicylic Acid, Abscisic Acid, Calcium, Hydrogen Peroxide, and Ethylene.” J. Plant Physiol. 161: 405-13.

[17] Bradford, M. M. 1976. “A Rapid and Sensitive Method for Quantitation or Microgram Quantities of Protein Utilizing the Principle of Protein-Dye Binding." Anal. Biochem. 72: 248-54.

[18] Laemmli, U. K. 1970. "Cleavage of Structural Proteins during the Assembly of the Head of Bacteriophage T4." 


\section{of Egyptian Barley Cultivars}

Nature 227 (5259): 680-5.

[19] Gomez, K. A., and Gomez, A. A. 1984. Statistical Procedures for Agriculture Research. 2nd edition. New York: John Wiley and Sons, 180.

[20] Saritha, V., Kuriakose, M., and Prasad, M. N. V. 2007. "Cadmium Stress Affects Seed Germination and Seedling Growth in Sorghum bicolor (L.) Moench by Changing the Activities of Hydrolyzing Enzymes." J. Plant Growth Regulation 54: 143-56.

[21] Ragab, A. A. M., Hellal, F. A., and Abd El-Hady, M. 2008. "Water Salinity Impacts on Some Soil Properties and Nutrients Uptake by Wheat Plants in Sandy and Calcareous Soil." Australian Journal of Basic and
Applied Sciences 2 (2): 225-33.

[22] Naseer, Sh., Nisar, A., and Ashraf, M. 2001. "Effect of Salt Stress on Germination and Seedling Growth of Barley (Hordeum vulgare L.).” Pakistan J. Biol. Sci. 4 (3): 359-60.

[23] Rehman, S., Harris, P. J. C., Bourne, W. F., and Wilkin, J. 2000. "The Relationship between Ions, Vigor and Salinity Tolerance of Acacia Seeds.” Plant and Soil 220: 229-33.

[24] Kong-Ngern, K., Daduang, S., Wongkham, C. H., Bunnag, S., Kosittrakun, M., and Theerakulpisut, P. 2005. "Protein Profiles in Response to Salt Stress in Leaf Sheaths of Rice Seedlings." Science Asia 31: 403-8. 